\title{
Drugs repurposing for COVID-19: phase III clinical trial evaluation
}

\author{
Woro Rukmi Pratiwi* \\ ${ }^{1}$ Department of Pharmacology and Therapy, Faculty of Medicine, Public Health and Nursing, \\ Universitas Gadjah Mada, Yogyakarta, Indonesia
}

https://doi.org/10.22146/ijpther.1228

Submitted: 19/01/2021

Accepted : 30/01/2021

Keywords:

COVID-19,

repurposing drugs, compassionate use, remdesivir,

favipiravir,

\begin{abstract}
World Health Organization (WHO) has announced coronavirus disease 2019 (COVID-19) as a global pandemic which is the largest public health crisis in this century. The spread of COVID-19 is still not well-controlled even become global health threat. As new disease, the specific drugs for COVID-19 have not been available, yet. Face of this condition, repurposing existing drugs become the best options in order to meet the urgently need of the effective drugs. In this article, the clinical trial results of some drugs for the treatment of COVID-19 included hydroxychloroquine, chloroquine, lopinavir/ritonavir, remdesivir, oseltamivir, favipiravir, and corticosteroids were reviewed. Hydroxychloroquine, choloquine and lopinavir/ritonavir were shown to be ineffective. Therefore, they were excluded from the list of drugs for the tratment of COVID-19 by WHO and the National Agency of Drug and Food Control of Republic of Indonesia (NCDE NADFC RI). Furthermore, NA-DFC RI has issued an emergency use authorization (EUA) for the use of remdesivir and favipiravir for the treatment of COVID-19.
\end{abstract}

\begin{abstract}
ABSTRAK
WHO telah mengumumkan COVID-19 sebagai pandemi global yang merupakan krisis kesehatan masyarakat terbesar abad ini. Penyebaran COVID-19 masih belum terkontrol dengan baik bahkan menjadi ancaman kesehatan global. Sebagai penyakit baru, obat spesifik untuk COVID-19 belum tersedia. Menghadapi kondisi ini, penggunaan kembali obat yang tersedia menjadi pilihan terbaik untuk memenuhi kebutuhan yang mendesak akan obat yang efektif. Makalah ini menelaah hasil penelitian klinik beberapa obat untuk pengobatan COVID-19 seperti hidroksiklorokuin, klorokuin, lopinavir/ritonavir, remdesivir, oseltamivir, favipiravir dan kortikosteroid. Hidroksiklorokuin, klorokuin, lopinavir/ritonavir terbukti tidak efektif, sehingga dikeluarkan dari daftar obat untuk pengobatan COVID-19 oleh WHO dan BPOM RI. Selanjutnya, BPOM RI telah mengeluarkan EUA untuk penggunaan remdesivir dan favipiravir untuk pengobatan COVID-19.
\end{abstract}

\section{INTRODUCTION}

The first case of coronavirus disease 2019 (COVID-19) was found in December 2019 in Wuhan, China. Within a few weeks, the virus has spread to all parts of China. It has also spread to other countries within one month. The total number of confirmed cases of COVID-19 globally as of December 5, 2020 was $65,257,767$ cases, with 1,513,179 deaths in 219 affected countries. ${ }^{1}$ The list of countries affected by COVID-19 might increase every day as the virus spreads to other countries.

The first confirmed cases of COVID-19 in Indonesia were reported on March 2, 2020 amounting to two infected people. As of December 31, 2020, COVID-19 cases in Indonesia have reached 743,198 confirmed cases. With this number, Indonesia ranked $21^{\text {st }}$ in the world for the total cumulative cases of COVID-19, with 22,138 deaths. ${ }^{2,3}$ Case fatality rate (CFR) due to COVID-19 in Indonesia was 3.1\%, which was considered as high compared 
to the global CFR, which was $2.3 \% .^{1}$ To date, World Health Organization (WHO) has announced COVID-19 as a global pandemic and it is bilieved as the largest public health crisis in this century. The spread of COVID-19 is still not wellcontrolled until now, even become global health threat.

The COVID-19 is caused by severe acute respiratory syndrome coronavirus 2 (SARS-CoV-2), which is one of the SARS species. The host receptor for SARS-CoV-2 cells entry is the same as for SARS-CoV, which is the angiotensinconverting enzyme 2 (ACE2). SARS-CoV-2 binds to ACE2 via the receptor-binding gene region of its spike protein. Similar to other viruses, SARS-CoV-2 mutates over time. Most mutations in the SARSCoV-2 genome have no impact on viral function. Specific variants have attracted wide attention because of their rapid presence in population and transmission potential or clinical implications. The symptoms of patients infected by SARSCoV-2 include mild symptoms to severe respiratory failure with multiple organ failure. ${ }^{4-7}$

As new disease, the specific drugs for COVID-19 have not been available, yet. Face of this condition, repurposing existing drugs become the best options in order to obtain the urgently need of the effective drugs. During this pandemic, WHO launched the Global Solidarity Trial involving research institutions at the national and international levels to evalaute the efficacy and safety of potential drugs for the treatment of COVID-19.8-10 Some antimalarial, antiviral and corticosteroids have been evaluated for their efficacy and safety for the treatment of COVID-19 through multicenter phase III clinical trial in some countries coordinated by WHO. In this article, the clinical trial results of some drugs for the treatment of COVID-19 included hydroxychloroquine, lopinavir/ ritonavir, remdesivir, oseltamivir, favipiravir, and corticosteroids were reviewed.

\section{DISCUSSION}

\section{Development of COVID-19 therapy by WHO}

On March 18, 2020, WHO announced the implementation of an international scale clinical trial named the Global Solidarity Trial in order to obtain safe and efficacious drugs for the treatment of COVID-19, at a lower cost and in a shorter time. More than 116 countries in six WHO regions were joined or interested to participate in the Global Solidarity Trial..$^{8,10}$ Indonesia participated in the Solidarity Trial on April 23, 2020, coordinated by the National Institute of Health Research and Development, Indonesian Ministry of Health, Republic of Indonesia. Since October 2, 2020. More than 12,000 patients from 30 countries have been recruited for the clinical trial.

The list of drugs for clinical trials against COVID-19 have been published on March 21,2020. The drugs varied included corticosteroids, chloroquine (to prevent and treat malaria), lopinavir/ritonavir, darunavir, emtricitabine/tenofovir (each drug/drug combination is used to treat HIV), ruxolitinib (to treat myelofibrosis and polycythaemia vera), baricitinib (to treat rheumatoid arthritis), sirolimus (as immunosuppressantin kidney transplant patients) and interferon $\alpha, \beta$, and $\gamma$ (to treat hepatitis B and C, melanoma, or multiple sclerosis). ${ }^{8,9}$ Some of these drugs have been discontinued during the trial due to not promosing included lopinavir/ ritonavir (discontinued on July 4, 2020), combination of lopinavir/ritonavir with interferon- $\beta$ (discontinued on July 4, 2020) and hydroxychloroquine (discontinued on June 18, 2020).

\section{Drug evaluation process based on evidence based medicine (EBM)}

The drug approval process begins by assessing the development of tested drugs in preclinical testing, then phase I, II, and III of clinical trials. Preclinical tests on experimental animal models include activity, acute toxicity, subchronic, dose 
dependence, metabolism, kinetics, carcinogenicity, and mutagenicity/ teratogenicity tests. Phase I of clinical trial is then carried out on healthy volunteers of 20-50 subjects to collect initial data on who will be given a single dose. Phase II of clinical trial is carried out on patients with a diagnosis according to the criteria for the disease given stratified doses to assess the safety and recommended dosage. Phase III of clinical trial is carried out on 250-4,000 patients in various groups to evaluate the safety and efficacy of the tested drugs compared to the existing standard drugs. After the safety and effectiveness of the drugs have been demonstrated through the phase III of clinical trial, then the drugs can be registered and distributed. Drug approval assessments are also based on postmarketing surveillance data from phase IV of clinical trial and spontaneous reporting system. Phase IV of clinical trial aims to determine the actual pattern of safety and effectiveness of drugs in the community. Postmarketing surveillance also records spontaneous reporting as pharmacovigilance data. Data come from communities reporting suspected adverse drug reactions (ADRs) to local or national pharmacovigilance centers. ${ }^{11,12}$ Drugs which will have distribution permit in Indonesia are assessed by the National Committee on Drug Evaluation, National Agency of Drug and Food Control of Republic of Indonesia/NCDE-NADFC RI (Komisi Nasional Penilaian Obat Jadi, Badan Pemeriksa Obat dan Makanan, Republik Indonesia/KOMNAS POJ, BPOM $\mathrm{RI}$ ). Drugs will have distribution permit in accordance to the indications submitted by the registrant (pharmaceutical industry). The documents which are assessed include preclinical test, phase I, II, and III of clinical trials, and periodic safety update report (PSUR) data in the form of pharmacovigilance data. Only preclinical test, phase I, II, and III of clinical trials with a good design and following the proposed indications can be considered for acceptance evaluation by NCDE. Phase III of clinical trial data with randomized controlled trial (RCT) design and meta-analysis, appropriate sample size, good safety profile, and conformity to guidelines (WHO, USFDA, EMA, TGA, etc.) are the primary considerations for drugs assessment. ${ }^{11,13}$ There is a 'compassionate use' scheme for the use of drugs that are under development and submitted for clinical trials, but have never received a distribution permit previously. The use of these drugs is for the treatment of COVID-19 with any indications and in emergency to be further developed in phase III of clinical trial with a RCT design. Emergency Use Authorization (EUA) is the policy in every country which allows temporary use of drugs that are already distributed for new indications during a pandemic. The EUA has only used emergency authorities twice. The first one was during the "swine flu" outbreak in 2009-2010. At the time, the EUA permitted intravenous peramivir (neuraminidase inhibitor) for $\mathrm{H}_{1} \mathrm{~N}_{1}$ influenza. However, the clinical trials conducted could not demonstrate the efficacy of peramivir over placebo in severely ill hospitalized patients with influenza. In 2014, peramivir is indicated only for uncomplicated influenza and not for use in severely ill hospitalized patients with influenza. During the COVID-19 pandemic, a similar scheme was undertaken for hydroxychloroquine, remdesivir, and favipiravir as therapies for COVID-19. ${ }^{14-17}$

\section{Clinical trial evaluation of old drugs against COVID-19}

World Health Organization and other research institutions at the national and international levels have carried out clinical trials aimed to demonstrate the efficacy and safety of tested drugs that have the potential for the treatment of COVID-19.9,18 Clinical trials are carried out on general population groups, not on particular groups such as pregnant/nursing mothers, children, and people with chronic diseases. Various studies and clinical trials are still ongoing in several countries, 
including in Indonesia. The evaluation of hydroxychloroquine, lopinavir/ ritonavir, remdesivir, oseltamivir, favipiravir, and corticosteroids used for the treatment of COVID-19 patient in 2020 are discussed in the following.

\section{Hydroxychloroquine}

Hydroxychloroquine (HCQ) and chloroquine (CQ) are 4-aminoquinoline which have been developed more than 70 years ago for the treatment of malaria and rheumatology. They have been proposed as treatments for COVID-19 based on in vitro activity and data from clinical studies. The CQ has been shown to have in vitro activity against various viruses, including SARS-CoV-2 and SARS$\mathrm{CoV}-1$. It can increase endosome $\mathrm{pH}$ by blocking the fusion of virus and host cell membranes or interfering with ACE2 glycosylated cells which are the cellular receptors of SARS-CoV. CQ can also suppress pro-inflammatory signal and cytokine production (IL-1, IL-6, and TNF) by inhibiting lysosome activity on cell antigen presentation. The level of 4-aminoquinoline which was required to inhibit SARS-CoV-2 replication in vitro was higher than for the prevention and treatment of malaria. Compared to CQ, HCQ has an additional hydroxyl group, lower toxicity, and similar antiviral efficacy. ${ }^{19,20}$

There are six studies regarding phase III of clinical trial conducted to evaluate HCQ for the treatment of COVID-19 compared with the usual/standard of care in this discussion. The first one is the Randomized Evaluation of COVID-19 Therapy (RECOVERY). This was an openlabel platform trial with a range of possible treatments compared with the usual care in patients admitted to hospital with COVID-19. The trial to evaluate HCQ was conducted in 176 hospitals in the United Kingdom (UK) from March 19 to June 29, 2020. The primary outcome was 28-day mortality. Part of this study examined the efficacy and safety of HCQ compared with the usual care. This study also examined dexamethasone and lopinavir/ritonavir versus usual care, and are discussed in other subsections. To date, this trial continued on assessing the effectiveness of azithromycin, tocilizumab, convalescent plasma, and REGN-COV2 to treat COVID-19 patients. A total of 4,716 subjects were randomized and divided into two groups. One group received HCQ sulfate in the form of a $200 \mathrm{mg}$ tablet containing a $155 \mathrm{mg}$ base equivalent $(n=1,430)$, while the other one received usual care $(n=3,155)$. The administration of HCQ was a loading dose of four tablets (total dose, 800 $\mathrm{mg}$ ) at baseline and at $6 \mathrm{~h}$, which was followed by two tablets (total dose, 400 $\mathrm{mg}$ ) starting at $12 \mathrm{~h}$ after the initial dose and then every $12 \mathrm{~h}$ for the next nine days or until discharge. The observation of subjects in the HCQ group was ceased on June 5, 2020 after an interim analysis showed that the effectiveness of HCQ was lacking. Mortality within 28 days occurred in $421(27.0 \%)$ patients treated by HCQ and in 790 (25.0\%) patients treated by the usual care (rate ratio, 1.09; $95 \% \mathrm{CI} ; 0.97$ to $1.23 ; \mathrm{p}=0.15){ }^{21}$

The second one is the phase III of clinical trial that was carried out in 11 hospitals in Taiwan, between April 1 and May 31, 2020, with the RCT design ( $n=33$, HCQ group with 21 subjects versus standard of care with 12 subjects) and retrospective study ( $\mathrm{n}=37$, HCQ group with 28 subjects versus standard of care with nine subjects). This clinical trial aimed to assess the efficacy and safety of HCQ (400 mg twice daily or $200 \mathrm{mg}$ twice daily for six days) compared with the standard of care in mild to moderate COVID-19 patients. The results of the RCT study showed that the median time for negative rRT-PCR was 5 days (95\%CI: 1 to 9 days) and 1 days (95\% CI: 2 to 12 days) for the HCQ and standard of care groups $(p=0.40)$, respectively. In contrast, the retrospective study results showed that the median time was 15 days for the HCQ group and 14 days for the standard of care group that had negative rRT-PCR results $(p=0.37)$. On day 14 , the virus was undetectable in $81.0 \%$ of the HCQ 
group and in $75.0 \%$ of the standard of care group $(p=0.36)$ in the RCT study. On the other hand, in the retrospective study, the virus was not detected in $42.9 \%$ of the HCQ group and $55.6 \%$ of the standard of care group $(p=0.70)$. No severe adverse events were reported in this clinical trial. Reported minor side effects in the HCQ group included headache (21.1\%), dizziness (5.3\%), gastritis (5.3\%), diarrhea (5.3\%), nausea (5.3\%), and photophobia (5.3\%). The median QTc (ranges) were $429.5 \mathrm{msec}$ (340-467) on day 4 and $421 \mathrm{msec}$ (391462) on day 8. No severe prolongation was noted. ${ }^{22}$

The third one is the phase III of clinical trial that was carried out to examine the efficacy and safety of HCQ at the Renmin Hospital of Wuhan University, from February 4 to February 28,2020 , on 62 patients suffering from COVID-19. The HCQ group $(n=31)$ received hydroxychloroquine sulfate tablets (Shanghai Pharma) $400 \mathrm{mg} / \mathrm{d}$ (200 $\mathrm{mg} / \mathrm{bid}$ ) between days 1 and 5, and were compared with the standard of care group $(n=31)$. The outcome was assessed as changes in time to clinical recovery (improvement in fever and cough as well as progressed to severe illness). Clinical improvement was faster in the HCQ than the standard of care groups in terms of no fever 2.2 versus 3.2 days $(p=0.0008)$, no cough 2 versus 3.1 days $(p=0.0016)$, and progressed to severe illness 0 versus $12.9 \%$, respectively. In addition, the improvement of pneumonia features in the HCQ group was $80.6 \%$, and the standard of care group was $54.8 \%$ $(p=0.0476)$. It was reported that two people experienced minor side effects of HCQ, i.e. one person experienced a rash and one person had a headache. ${ }^{23}$

The fourth phase III of clinical trial is the RCT to test HCQ in nonhospitalized adults with early symptoms of COVID-19 in the United States (US) and Canada (40 states and three provinces). A total of 491 symptomatic, non-hospitalized adults with laboratory-confirmed of COVID-19 or probable COVID-19 were administered with oral HCQ (800 mg once, followed by $600 \mathrm{mg}$ in 6 to $8 \mathrm{~h}$, then $600 \mathrm{mg}$ daily for four more days) $(n=244)$ or masked placebo $(n=247)$. The 14-day change in symptoms severity did not differ much between the HCQ and placebo groups (difference in symptoms severity: relative, $12 \%$; absolute, -0.27 points [95\% CI: -0.61 to 0.07 points]; $\mathrm{p}=0.117)$. On the $14^{\text {th }}$ day, $24 \%$ of the HCQ group still had symptoms compared with $30 \%$ of the placebo group $(p=0.21)$. Adverse effect of the treatment was observed in $43 \%$ of the HCQ group versus $22 \%$ of the placebo group ( $<<0.001)$. With HCQ, gastrointestinal symptoms were the most common reported adverse effect, i.e. $31 \%$ of participants reported upset stomach or nausea and $24 \%$ reported abdominal pain, diarrhea, or vomiting. ${ }^{24}$

The fifth phase III of clinical trial is the study conducted by Tang et al. ${ }^{25}$ In this study, the use of HCQ in patients with mainly mild to moderate COVID-19 was reviewed, involving 16 hospitals in China from February 11 to 29, 2020. The subjects were 150 patients (148 had mild to moderate symptoms and two had severe symptoms). They were administered with HCQ randomly $(n=75)$ plus standard of care or standard of care alone $(n=75)$. Hydroxichloroquine was administered at a loading dose of $1,200 \mathrm{mg}$ daily for 3 days, followed by a maintenance dose of $800 \mathrm{mg}$ daily (total treatment duration: 2 or 3 weeks for patients with mild to moderate or severe symptoms, respectively). The probability of negative conversion of SARSCoV-2 for 28 days in the HCQ group was $85.4 \%$ (95\% CI: 73.8 to 93.8\%), while in the standard of care group was $81.3 \%$ $(95 \% \mathrm{CI} ; 71.2$ to $89.6 \%)$. The median time of negative conversion in the HCQ group was 8 days (95\% CI: 5 to 10 days), whereas the standard of care group was 7 days (95\% CI: 5 to 8 days). Side effect reported in the HCQ group was diarrhea ( $10 \%$ of patients), whereas no side effect found in the standard of care group. Hydroxichloroquine was discontinued in one patient due to blurred vision. 
The dose was lowered in one patient reporting thirst. The two adverse events were temporary; they only lasted one to two days. It can be concluded that HCQ administration was no more effective than standard treatment. ${ }^{25}$

The last study on phase III of clinical trial on the use of HCQ discussed in this review is the one conducted by Cavalcanti et al. ${ }^{26}$ In this study, the use of HCQ was examined in patients with mainly mild to moderate COVID-19. It was a multicenter randomized openlabel three-group controlled trial involving hospitalized patients with suspected or confirmed COVID-19 involving 55 hospitals in Brazil. Patients $(n=665)$ were randomly assigned in a 1: 1: 1 ratio to receive standard of care (control group, $n=227$ ), standard of care plus HCQ at a dose of $400 \mathrm{mg}$ twice daily for 7 days (HCQ-alone group, $n=221$ ), or standard of care plus HCQ at a dose of $400 \mathrm{mg}$ twice daily plus azithromycin at a dose of $500 \mathrm{mg}$ once a day for 7 days (HCQ/azithromycin group, $\mathrm{n}=217$ ). The primary outcome was the clinical status on the $15^{\text {th }}$ day. Among the patients with confirmed COVID-19, there was no significant difference in clinical status on the $15^{\text {th }}$ day between the three groups: HCQ plus azithromycin versus control (odds ratio $=0.99 ; 95 \% \mathrm{CI}$ : 0.57 to 1.73 ; $\mathrm{p}=1.00$ ); HCQ alone versus control (odds ratio $=1.21$; $95 \% \mathrm{CI}$ : 0.69 to $2.11 ; \mathrm{p}=1.00$ ); and HCQ plus azithromycin versus HCQ alone (odds ratio $=0.82 ; 95 \%$ CI: 0.47 to 1.43; $\mathrm{p}=1.00$ ). QTc prolongation was more common in patients receiving HCQ plus azithromycin or HCQ alone than in patients in the control group. Elevated liver enzyme levels were more common in patients receiving HCQ plus azithromycin than in the control group. ${ }^{26}$

Based on the clinical trial results that have been discussed, HCQ has been shown to be ineffective. WHO have instructed to stop the use of HCQ on June 18, 2020 as tested drugs for COVID-19 patients. Furthermore, NA-DFC does not include HCQ in the Information of COVID-19 Drug $2^{\text {nd }}$ edition (IOCI 2/Informatorium Obat COVID-19) in
Indonesia published in November $2020 .^{8,20}$

\section{Lopinavir/ritonavir}

Lopinavir is an antiretroviral protease inhibitor used in combination with other antiretroviral drugs in the second-line treatment of HIV/ AIDS infection. The dosage form of lopinavir should be used in combination with ritonavir due to the low oral bioavailability and extensive biotransformation of lopinavir. Ritonavir is a potent inhibitor of the enzyme responsible for lopinavir metabolism. The concomitant use of these drugs "increases" lopinavir bioavailabity and antiviral activity. ${ }^{27,28}$

There are 3 studies regarding phase III of clinical trial in order to evaluate lopinavir/ritonavir for the treatment of COVID-19 compared with the usual/ standard of care in this discussion. The first study is the Global Solidarity Trial involving 405 hospitals in 30 countries. The study recruited 11,330 subjects who received remdesivir (2,750 subjects), HCQ (954 subjects), lopinavir (1,411 subjects), interferon (2,063 subjects, including 651 receiving interferon plus lopinavir), and no drug (4,088 subjects). The lopinavir (oral) regimen was 2 tablets twice a day for 14 days. Each tablet contained $200 \mathrm{mg}$ of lopinavir plus $50 \mathrm{mg}$ of ritonavir. Lopinavir was only available in oral form, hence it could not be administered to the patients who were subjected to mechanical ventilation and those who could not swallow. The primary outcome assessed was inhospital mortality. In terms of lopinavir versus control group, the mortality was respectively 148 out of 1,399 patients versus 146 out of 1,372 patients $(\mathrm{RR}=$ 1.00; $95 \%$ CI: 0.79 to $1.25 ; \mathrm{p}=0.97$ ). The overall or subgroups results showed that no tested drug reduced mortality significantly. World Health Organization stopped the lopinavir/ritonavir regimen and declared that it was not effective in reducing the risk of death in COVID-19 patients in the hospital. ${ }^{15}$

The second study is the RECOVERY 
study to evaluate the efficacy and safety of lopinavir/ritonavir, together with HCQ and dexamethasone as previously discussed. RECOVERY subjects who received lopinavir/ritonavir and usual care treatments were 1,616 people and 3,424 people, respectively. Mortality was reported within 28 days in 374 (23\%) subjects in the lopinavir/ritonavir group and 767 (22\%) subjects in the usual care group (rate ratio=1.03; 95\% CI: 0.91 to $1.17 ; \mathrm{p}=0.60$ ). The result of this study showed that lopinavir/ritonavir did not reduce mortality within 28 days in hospitalized COVID-19 patients. ${ }^{29}$

The third study is the LOTUS China (Lopinavir Trial for Suppression of SARS-CoV-2 in China), which was a randomized controlled open-label trial conducted from January 18 to February 3, 2020 in Jin Yin-Tan Hospital, Wuhan, Hubei Province, China. The study was carried out in 199 COVID-19 patients who received lopinavir/ritonavir (400 $\mathrm{mg}$ and $100 \mathrm{mg}$ orally, respectively) twice daily plus standard of care $(n=99)$ or standard of care alone $(n=100)$ for 14 days. The standard of care included supplemental oxygen, non-invasive and invasive ventilation, antibiotic agents, vasopressor support, renal-replacement therapy, and extracorporeal membrane oxygenation (ECMO). The primary endpoint was the time to clinical improvement (improvement of two points on a seven-category ordinal scale or discharge from the hospital). The results showed that the time to clinical improvement in the lopinavir/ritonavir group was not different from standard of care (median, 16 days versus 16 days; HR for clinical improvement $=1.31 ; 95 \% \mathrm{CI}$ : 0.95 to $1.80 ; p=0.09)$. A total of $46(48.4 \%)$ patients in the lopinavir/ritonavir group and 49 (49.5\%) patients in the standard of care group experienced side effects. The side effects, such as nausea, vomiting, and diarrhea, were more common in the lopinavir/ritonavir group. Four serious gastrointestinal side effects were reported in the lopinavir/ ritonavir group, but there was none in the standard of care group. Lopinavir/ ritonavir treatment was stopped early in $13(13.8 \%)$ patients due to its side effects. ${ }^{30}$

Based on the clinical trial results that have been discusssed, lopinavir/ritonavir has been shown to be ineffective. WHO has instructed to stop the use of lopinavir/ ritonavir on July 4, 2020 as tested drug for COVID-19 patients. The NA-DFC does not include lopinavir/ritonavir in IOCI 2 published in November $2020 .^{8}$

\section{Remdesivir}

Remdesivir, a nucleotide analog prodrug that inhibits viral RNA polymerases, has shown in vitro activity against SARS-CoV-2. This prodrug is metabolized in the host cell to form the active adenosine triphosphate (ATP). Remdesivir triphosphate acts as an ATP analog and joins the RNA chain in SARSCoV-2. The result is inhibition of the RNA-dependent RNA polymerase (RdRp) enzyme, which causes the termination of RNA chain formation during viral RNA replication. ${ }^{5,31}$

There are 5 studies regarding phase III of clinical trial in order to evaluate the use of remdesivir for the treatment of COVID-19 in the following discussion. The first study is the Adaptive Covid-19 Treatment Trial (ACTT-1), which was a randomized double-blind placebocontrolled trial. The trial examined a 10-day remdesivir (200 $\mathrm{mg}$ on the first day, followed by $100 \mathrm{mg} /$ day) versus a 10-day placebo in patients with severe COVID-19. The outcome which was assessed was the recovery time and mortality. The study was conducted from February 21 to April 19, 2020, involving 60 trial sites and 13 subsites in the US (45 sites), Denmark (8), UK (5), Greece (4), Germany (3), Korea (2), Mexico (2), Spain (2), Japan (1), and Singapore (1). A total of 1,062 patients were randomly assigned to 2 groups, namely the remdesivir $(n=541)$ and placebo $(n=521)$ groups. The remdesivir group had a mean recovery time of 10 days (95\% CI; 9-11 days), whereas the placebo 
group was 15 days (95\% CI: 13-18 days) with recovery rate ratio 1.29 (95\% CI; 1.12 to $1.49 ; \mathrm{p}<0.001$, by log-rank test). The remdesivir group showed clinical improvement at day 15 (odds ratio, 1.5; 95\%CI: 1.2-1.9, after adjustment for actual disease severity) compared with placebo. Kaplan-Meier mortality estimations for the remdesivir versus placebo groups respectively were $6.7 \%$ versus $11.9 \%$ on the $15^{\text {th }}$ day and $11.4 \%$ versus $15.2 \%$ on the $29^{\text {th }}$ day (HR, 0.73 ; 95\%CI: 0.52 to 1.03$)$. Serious side effects were reported in $24.6 \%$ subjects in the remdesivir group and in $31.6 \%$ subjects in the placebo group. In addition, serious side effect of respiratory failure was observed in both the remdesivir $(8.8 \%$ patients) and placebo (15.5\% patients) groups. No deaths were associated with therapy. The results of this study showed that remdesivir was effective and had lower side effects than placebo. ${ }^{32}$

The second study is RCT conducted by Spinner et $a{ }^{33}$ In this study, the efficacy of remdesivir in moderate COVID-19 patients (pulmonary infiltrates and room-air oxygen saturation $>94 \%$ ) was examined. The study was conducted in 105 hospitals in the US, Europe, and Asia from March to April 2020. The subjects were randomly assigned into three groups. Each group received remdesivir for 10 days $(n=197)$ and 5 days $(n=199)$ or standard of care $(n=200)$ treatments. Remdesivir was administered intravenously at $200 \mathrm{mg}$ on the first day, followed by $100 \mathrm{mg} /$ day. The primary outcome was the clinical status on the day 11 on a 7-point ordinal scale, ranging from death (category 1) to discharge (category 7). Most of the subjects suffered from cardiovascular disease (56\%), hypertension (42\%), and diabetes (40\%). The 5-day remdesivir group had better clinical status than the standard of care group $(\mathrm{OR}=1.65 ; 95 \% \mathrm{CI}$ : 1.09-2.48; $p=0.02)$. In contrast, the clinical status of the 10-day remdesivir group versus the standard of care group did not differ significantly $(\mathrm{p}=0.18$ by Wilcoxon rank-sum test). The reported effects of nausea (10\% versus 3\%), hypokalemia $(6 \%$ versus $2 \%)$, and headache $(5 \%$ versus $3 \%$ ) were more frequent from the remdesivir group than in standard of care group..$^{33}$

The third study is also a RCT by Goldman et al. $^{34}$ In this study, the efficacy of remdesivir in severe COVID-19 patients was examined. The study was conducted in 55 hospitals in the US, Italy, Spain, Germany, Hong Kong, Singapore, South Korea, and Taiwan from March 6 to March 26, 2020. The subjects were randomly divided into 2 groups. Each group received remdesivir treatment for 10 days $(n=197)$ or 5 days $(n=200)$. Remdesivir was administered intravenously at $200 \mathrm{mg}$ on the first day, followed by $100 \mathrm{mg} /$ day. The primary outcome was the clinical status on the day 14 on a 7-point ordinal scale. The baseline data of the 10-day remdesivir group were worse than the 5 day remdesivir group $(p=0.02)$. On day 14 , the clinical improvement occurred in 54\% of subjects in the 10 day and $64 \%$ in the 5 day groups. The 10 day group showed no difference in clinical status on the day 14 than the 5 day group $(p=0.14)$. The reported side effects were nausea (9\%), worsening respiratory failure (8\%), elevated alanine aminotransferase level (7\%), and constipation (7\%). This study did not compare with placebo (standard of care). ${ }^{34}$

The fourth study is conducted by Wang et al. ${ }^{35}$ In this study, a double-blind placebo-controlled multicentre trial was conducted in 10 hospitals in Hubei, China from February 6 to March 12, 2020. This study examined the administration of remdesivir (200 $\mathrm{mg}$ on the first day, followed by $100 \mathrm{mg} /$ day) for 10 days compared with a placebo for 10 days in patients with severe COVID-19. The patients were permitted concomitant use of lopinavir/ritonavir, interferons, and corticosteroids. The primary endpoint was time for clinical improvement up to 28 days. A total of 237 patients were randomly assigned into two groups of remdesivir (158 subjects) and placebo 
(79 subjects). The study results showed that there was no difference in clinical improvement time between the remdesivir group (median 21.0 days) versus placebo (median 23.0 days) (HR=1.27; 95\%CI: 0.89 to 1.80). However, clinical improvement was faster in the remdesivir group than placebo on day 14 (27\% versus $23 \%$ ) and (65\% versus $58 \%$ ) although not statistically significant. According to the investigators, it was because the number of subjects was small. The most frequent side effects found in the remdesivir group to the least frequent ones were constipation, hypoalbuminemia, hypokalemia, anemia, and thrombocytopenia, and increased total bilirubin. In contrast, the most frequent side effects found in the placebo group were hypoalbuminemia, constipation, anemia, hypokalemia, increased aspartate aminotransferase, increased blood lipids, and increased total bilirubin. The serious side effects in the remdesivir group were less (18\%) than the placebo group (26\%). More patients discontinued the drug being tested because of the frequent side effects or serious side effects in the remdesivir group (12\%) than the placebo group (5\%). However, all deaths assessed by the investigators were not associated with the study. ${ }^{35}$

The fifth study is the Solidarity Trial. This trial reported deaths in 301 out of 2,743 patients in the remdesivir group and 303 out of 2,708 patients in the remdesivir control group $(\mathrm{RR}=0.95$; 95\% CI: 0.81 to $1.11 ; \mathrm{p}=0.50$ ). It was found that overall or in a subgroup, none of the tested drugs reduced mortality. ${ }^{15,36}$

Based on the 5 studies that have been discussed, it is clear that remdesivir (200 mg on the first day, followed by 100 $\mathrm{mg} /$ day) has a clinical improvement effect and relatively fewer side effects compared with placebo (standard of care) in patients with severe COVID-19. In addition, it was demonstrated to be able to reduce mortality and shorten recovery time in comparison with the placebo group. ${ }^{32-35}$ Five-days treatment with remdesivir showed better results than 10-days treatment in moderate and severe COVID-19 patients. ${ }^{33,34}$ However, the Global Solidarity Trial showed different results compared with other clinical trials, which might be due to differences in the study designs and the severity of COVID-19 symptoms in patients. ${ }^{36}$ The NA-DFC has issued the EUA since September 19, 2020 for remdesivir. ${ }^{37}$ In IOCI 2, the use of remdesivir is for the treatment of patients with confirmed COVID-19 in adults and adolescents (aged 12 years or over who weigh $40 \mathrm{~kg}$ or more) and also in hospitalized COVID-19 patients with severe symptoms. The degree of severety is shown by oxygen saturation $(\mathrm{SpO} 2) \leq 94 \%$ or additional oxygen requirement and/or ventilator or ECMO requirements. ${ }^{8}$

\section{Oseltamivir}

Oseltamivir phosphate is a prodrug of oseltamivir carboxylate (OC), which is a selective and potent inhibitor of the neuraminidase of influenza $A$ and $B$ viruses, thereby inhibiting influenza virus infection and in vitro viral replication. Viral neuraminidase plays a significant role in releasing newly formed viral particles from the infected cells and the spread of virus transmission. ${ }^{37}$ Oseltamivir has been approved by the NA-DFC before the COVID-19 pandemic as an influenza therapy in adults and children aged one year or older with typical influenza symptoms, if the virus is circulating in an environment. Oseltamivir can also be used to prevent influenza in adults and children over 13 years. ${ }^{38}$ In an in silico assessment, in vitro, and retrospective study of oseltamivir conducted by Tan et $a .^{38}$ the results showed that oseltamivir was ineffective at reducing symptoms and slowing the progression of COVID-19; although at the beginning of oseltamivir use, symptoms were reduced. There are insufficient strong data to support the use of oseltamivir for the treatment of COVID-19. ${ }^{39}$ 
As stated by the NIH COVID-19 Treatment Guidelines, oseltamivir can be given to hospitalized patients suspected of being infected by SARSCoV-2, influenza, or both (coinfection) without waiting for a positive result of influenza infection. However, if the test results do not indicate influenza infection, then oseltamivir administration should be stopped. Oseltamivir is included IOCI 2 for mild, moderate, and severe symptoms if coinfection of influenza and COVID-19 is suspected. ${ }^{8}$

\section{Favipiravir}

Favipiravir selectively inhibits RNAdependent RNA polymerase (RdRp) of influenza viruses. Favipiravir is a prodrug that undergoes ribosylation and intracellular phosphorylation and is converted into ribofuranosyl phosphate (favipiravir-RFP) in cells. It is then recognized as a substrate by viral RNA polymerase, thereby inhibiting the RNA polymerase activity and the viral replication. ${ }^{40}$

There are three studies regarding phase III of clinical trial in order to evaluate the use of favipiravir for the treatment of COVID-19 in the following discussion. The first study is the RCT conducted by Cai et al. ${ }^{41}$ which was an open-label nonrandomized before-after controlled study in an isolation ward of the National Clinical Research Center for Infectious Diseases (the Third People's Hospital of Shenzhen), Shenzhen, China, from January 30 to February 14, 2020. This study aimed to examine favipiravir (day 1: 1,600 mg twice daily; Day 2-14: $600 \mathrm{mg}$ twice daily) which was administered orally with interferon (IFN)- $\alpha$ by aerosol inhalation (5 million IU twice daily) compared with lopinavir/ ritonavir (Day 1-14: $400 \mathrm{mg} / 100 \mathrm{mg}$, respectively, twice daily) which was administered orally with IFN- $\alpha$ by aerosol inhalation (5 million IU twice daily) as the control. The assessment for the outcome was the time of viral clearance and the improvement rate of chest computed tomography (CT) scans on day 14 after treatment. Eighty patients were randomly assigned into two groups of favipiravir (35 subjects) and control (45 subjects) groups. The results of the study showed that the median time of viral clearance in the favipiravir group was shorter (4 days) than the in the control group (11 days) (IQR: $8-13)(p<0.001)$. On day 14, after the treatment, the rate of improvement from chest $\mathrm{CT}$ in the favipiravir group was higher than in the control group (91.4\% versus $62.2 \%$; $p=0.004)$. The side effects reported by the favipiravir group (11.43\%) were fewer than the control group $(55.56 \%)(\mathrm{p}<0.001)$. The side effects of favipiravir included diarrhea, liver injury, and a poor diet. The results of this study provide useful information for the treatment of SARS-CoV-2 infection. ${ }^{41}$

The second study is conducted by Chen et al. ${ }^{40}$ which was a multicenter open-label randomized superiority trial in 3 hospitals (Zhongnan Hospital of Wuhan University, Leishenshan Hospital, and The Third People's Hospital of Hubei Province) from February 20 to March 12, 2020. This study compared the efficacy and safety of favipiravir and arbidol as therapies for COVID-19 on a seven-day clinical recovery rate. The subjects were divided into two groups of conventional therapy plus favipiravir $(p=120)$ or conventional therapy plus arbidol $(n=120)$ groups. The results showed that the seven-day clinical recovery rate in the favipiravir group was better than the arbidol group (71.43\% versus 55.86\%; $\mathrm{p}=0.0199)$. Favipiravir maybe the treatment of choice for COVID-19 due to the high 7-day clinical recovery rate. ${ }^{41}$

The third study is conducted by Doi et al. ${ }^{42}$ which was a prospective randomized open-label multicenter trial to assess the efficacy of favipiravir in patients with asymptomatic to mildly symptomatic COVID-19. The study was carried out in 25 hospitals across Japan from March 2 to June 14, 2020. The patients were randomly administered 
with favipiravir on day 1 (early treatment group) ( $n=44$ subjects) or on day 6 of study participation (late treatment group) ( $n=44$ subjects). The assessment for the outcomes were viral clearance on day 6 and change in viral load on day 6 . Viral clearance on day 6 in the early treatment group was faster than in the late treatment group, i.e. $66.7 \%$ versus $56.1 \%$ (adjusted $\mathrm{HR}=1.42$; 95\%CI: 0.76 to 2.62). Negative changes in viral load were faster in the early treatment group than in the late treatment group, i.e. $94.4 \%$ versus $78.8 \%$ (adjusted $\mathrm{OR}=4.750$; 95\% CI: 0.876 to 25.764). Neither disease progression nor death occurred during the 28 days of the study. ${ }^{42}$

Based on the clinical trials that have been discussed, favipiravir showed to be effective for the treatment of COVID-19. The NA-DFC has issued the EUA for favipiravir on September 3, 2020.43 In IOCI 2, the use of favipiravir is for the treatment of COVID-19 adult patients ( $\geq 18$ years) with mild to moderate severity symptoms, combined with standard of care. ${ }^{8}$

\section{Corticosteroids}

As an anti-inflammatory, corticosteroids are expected to reduce lung injury in patients with COVID 19, thereby inhibiting respiratory failure and death. Corticosteroids used in clinical trials are dexamethasone. ${ }^{43,44}$ Indications for the use of dexamethasone are suppressing inflammation and allergic disorders, Cushing's disease, congenital adrenal hyperplasia, cerebral edema associated with pregnancy, cough accompanied by shortness of breath, and rheumatic disease. ${ }^{8}$ There are three studies regarding phase III of clinical trial in order to evaluate the use of corticosteroids for the treatment of COVID-19 in the following discussion. The first study is the preliminary report from the RECOVERY trial. In this trial, besides assessing HCQ and lopinavir/ ritonavir, the efficacy and safety of oral or intravenous dexamethasone $(6 \mathrm{mg}$ once daily) for ten days were compared with the standard of care. A total of 2,104 subjects received dexamethasone, while 4,321 subjects received standard of care. A total of 482 patients (22.9\%) in the dexamethasone group and 1,110 patients $(25.7 \%)$ in the standard of care group died within 28 days after randomization (age-adjusted rate ratio $=0.83 ; 95 \%$ CI: 0.75 to $0.93 ; \mathrm{p}<0.001$ ). In regard to mortality, proportional and absolute differences between groups varied widely according to the subjects' level of respiratory support at the time of randomization. The incidence of death in the dexamethasone group was lower than in the usual care group on subjects who received an invasive mechanical ventilation treatment $(29.3 \%$ vs $41.4 \%$; $\mathrm{RR}=0.64 ; 95 \% \mathrm{CI}: 0.51$ to 0.81 ) and on subjects who received oxygen without an invasive mechanical ventilation treatment $(23.3 \%$ versus $26.2 \%$; $\mathrm{RR}=$ 0.82; 95\%CI: 0.72-0.94). However, the incidence of death in the dexamethasone group was higher than in the usual care group on subjects who did not receive supplemental oxygen $(17.8 \%$ vs $14.0 \%$; $\mathrm{RR}=1.19 ; 95 \% \mathrm{CI}: 0.91$ to 1.55$)$. This result showed that oral or intravenous dexamethasone treatment (6 $\mathrm{mg}$ once a day) for ten days was able to reduce the mortality of patients with COVID-19 who received an invasive mechanical ventilation and supplemental oxygen treatments. ${ }^{43}$

The second study is the COVID-19 Dexamethasone (CoDEX) Randomized Clinical Trial, which was a multicenter randomized open-label clinical trial conducted in 41 intensive care units (ICUs) in Brazil. The subject were COVID-19 patients with moderate to severe ARDS. There were two groups in which the first group received dexamethasone of $20 \mathrm{mg}$ daily administered intravenously for five days, followed by $10 \mathrm{mg}$ daily for five days or until discharge from the ICU plus standard of care $(n=151)$ compared with the second group who received only standard of care $(n=148)$. The primary outcome was ventilator-free 
days during the first 28 days, defined as being alive and free from mechanical ventilation. The dexamethasone group had a mean of 6.6 ventilator-free days (95\% CI: 5.0 to 8.2) during the first 28 days versus 4.0 ventilator-free days $(95 \% \mathrm{CI}$ : 2.9 to 5.4 ) in the standard of care group (difference, 2.26; 95\% CI: 0.2 to 4.38; $\mathrm{p}=0.04$ ). On day 7 , the dexamethasone group had a mean SOFA score of 6.1 (95\% CI: 5.5 to 6.7 ) versus 7.5 (95\% CI: 6.9 to 8.1 ) in the standard of care group (difference, -1.16 ; 95\% CI: -1.94 to -0.38 ; $\mathrm{p}=0.004$ ). This study showed that in patients with COVID-19 with moderate or severe ARDS, the use of intravenous dexamethasone plus standard of care significantly increased the number of ventilator-free days during the first 28 days. ${ }^{44}$

The third study is the GLUCOCOVID, which was a partially randomized preference open-label controlled twoarm parallel-group trial, conducted in five hospitals in Spain from April to May 2020. The study aimed to assess the efficacy of corticosteroids addition (intravenous methylprednisolone 40 $\mathrm{mg} / 12 \mathrm{~h}$ three days, then $20 \mathrm{mg} / 12 \mathrm{~h}$ three days) in standard therapy for moderate to severe COVID-19 patients. The number of subjects was 85 patients and divided into the methylprednisolone $(p=56)$ and standard therapy $(\mathrm{p}=29)$ groups. The primary endpoint was a composite of death or admission to the intensive care unit (ICU) or the requirement of non-invasive ventilation (NIV). The study results showed that subjects who experienced in-hospital all-cause mortality or escalation at the ICU admission or progression of respiratory insufficiency that required NIV in the methylprednisolone group (24\%) were lower than those with standard therapy (48\%) $(\mathrm{RR}=0.5 ; 95 \% \mathrm{CI}: 0.27$ to 0.94). Decreased levels of C-reactive protein were more visible in the methylprednisolone group $(p=0.0003)$. Hyperglycemia (>180 mg/dL) occurred in the methylprednisolone group (21\%), but did not occur in the standard therapy group. ${ }^{45}$

World Health Organization and EMA recommended the use of systemic corticosteroids for COVID-19 patients with severe to critical symptoms, but do not recommend the use of systemic corticosteroids for COVID-19 patients with mild to moderate symptoms. To date, its status is registered as a tested drug for COVID-19 in Indonesia and several countries. The indications listed in IOCI 2 are anti-inflammatory in severe cases of COVID-19 who receive additional oxygen or using a mechanical ventilator. ${ }^{8}$

\section{CONCLUSION}

During the COVID-19 pandemic in 2020, specific therapies other than supportive care were studied. Based on the clinical trial results, it is apparent that HCQ and lopinavir/ritonavir are shown to be ineffective. Therefore, WHO and the NA-DFC excluded the HCQ (June 18, 2020) and lopinavir/ ritonavir (July 4,2020) for the tratment of COVID-19. Since September 3 and 19, 2020, the NA-DFC has issued the EUA for favipiravir and remdesivir, respectively. World Health Organization and EMA recommend the use of systemic corticosteroids for COVID-19 patients with severe to critical symptoms, but do not recommend the use of systemic corticosteroids for COVID-19 patients with mild to moderate symptoms.

\section{ACKNOWLEDGEMENT}

The author is very grateful to Prof. Dr. Erna Kristin, M.Si., Apt. for her valuable assistances in preparing this literature review.

\section{REFERENCES}

1. Kementrian Kesehatan Republik Indonesia. Situasi terkini perkembangan coronavirus disease19. 4 Januari 2021. Situasi Infeksi Emerging [Internet]. [cited 
2021 Jan 4]. Available from: https:// infeksiemerging.kemkes.go.id/ situasi-infeksi-emerging

2. Satuan Tugas Penanganan COVID-19. Sebanyak 611.097 Pasien Sembuh COVID-19 di Tahun 2020 [Internet]. [cited 2021 Jan 4]. Available from: https://COVID19.go.id/berita/ sebanyak-611097-pasien-sembuhCOVID-19-di-tahun-2020

3. World Health Organization. WHO Coronavirus Disease (COVID-19) Dashboard [Internet]. [cited 2021 Jan 4]. Available from: https://COVID19. who.int/table

4. Del Rio C, Malani P. Translating science on COVID-19 to improve clinical care and support the public health response. JAMA 2020; 323(24):2464-5.

https://doi.org/10.1001/jama.2020.9252

5. Cevik M, Kuppalli K, Kindrachuk J, Peiris M. Virology, transmission, and pathogenesis of SARS-CoV-2. BMJ 2020; 371:1-6.

https://doi.org/10.1136/bmj.m3862

6. Wiersinga WJ, Rhodes A, Cheng AC, Peacock SJ, Prescott HC. Pathophysiology, transmission, diagnosis, and treatment of coronavirus disease 2019 (COVID-19): A review. JAMA 2020; 324(8):782-93. https://doi.org/10.1001/jama.2020.12839

7. McIntosh K, Hirsch MS, Bloom A. Coronavirus disease 2019 (COVID-19): Epidemiology, virology, and prevention [Internet]. Dec 2020 [cited 2021 Jan 9]. Available from: https://www.uptodate.com/contents/ coronavirus-disease-2019-COVID19-epidemiology-virology-andprevention

8. BPOM RI. Informatorium obat COVID-19 di Indonesia. Jakarta: BPOM RI, 2020: 206.

9. World Health Organization. Landscape analysis of therapeutics as $21^{\text {st }}$ March 2020 [Internet]. 2020. [cited 2021 Jan 9]: 1-49 p. Available from: https://www.who. int/blueprint/priority-diseases/ key action/Table_of_therapeutics_
Appendix_17022020.pdf

10. World Health Organization. Offlabel use of medicines for COVID-19. WHO [Internet]. 2020;March [cited 2021 Jan 9]:3-5. Available from: https://www.who.int/news-room/ commentaries/detail/off-label-useof-medicines-for-COVID-19

11. US Food and Drug Administration. Development \& approval process drugs [Internet]. [cited 2021 Jan 8]. Available from: https://www.fda. gov/drugs/development-approvalprocess-drugs\#: :text=FDA approval of a drug, risks for the intended population.

12. CRB. The basics and the process of drug approval [Internet]. [cited 2021 Jan 10]. Available from: https:// www.crbgroup.com/insights/ pharmaceuticals/drug-approvalprocess

13. BPOM RI. Pedoman pelayanan publik di bidang obat dalam kondisi pandemi COVID-19. Jakarta: BPOM RI, 2020: 1-48.

14. Grein J, Ohmagari N, Shin D, Diaz $\mathrm{G}$, Asperges E, Castagna A, et al. Compassionate use of remdesivir for patients with severe COVID-19. N Engl J Med 2020; 382(24):2327-36. https://doi.org/10.1056/NEJMoa2007016

15. WHO Solidarity Trial Consortium. Repurposed antiviral drugs for COVID-19 - Interim WHO solidarity trial results. N Engl J Med 2020; NEJMoa2023184.

16. PREVAIL II Writing Group: MultiNational PREVAIL II Study Team. A randomized, controlled trial of ZMapp for ebola virus infection. N Engl J Med 2016; 375(15):1448-56. https://doi.org/10.1056/NEJMoa1604330

17. Sorbello A, Jones SC, Carter W, Struble K, Boucher R, Truffa M, et al. Emergency use authorization for intravenous peramivir: Evaluation of safety in the treatment of hospitalized patients infected with 2009 H1N1 influenza a virus. Clin Infect Dis 2012; 55(1):1-7. https://doi.org/10.1093/cid/cis351 
18. Pundi K, Perino AC, Harrington RA, Krumholz HM, Turakhia MP. Characteristics and strength of evidence of COVID-19 studies registered on clinical trials. gov JAMA Intern Med 2020; 180(10):1398-400.

h t t p s://d o i.org/10.1001/ jamainternmed.2020.2904

19. Zachariah P, Johnson CL, Halabi KC, Ahn D, Sen AI, Fischer A, et al. Epidemiology, clinical features, and disease severity in patients with coronavirus disease 2019 (COVID-19) in a children's hospital in New York City, New York. JAMA Pediatr 2020; 174(10):1-7.

h t t p s://d oi.org/10.1001/ jamapediatrics.2020.2430

20. Vinetz JM. Lack of efficacy of hydroxychloroquine in COVID-19. BMJ 2020; 369:1-2.

https://doi.org/10.1136/bmj.m2018

21. RC Group. Effect of hydroxychloroquine in hospitalized patients with COVID-19. N Engl J Med 2020; 383(21):2030-40.

https://doi.org/10.1056/NEJMoa2022926

22. Chen CP, Lin YC, Chen TC, Tseng TY, Wong HL, Kuo CY, et al. A multicenter, randomized, open-label, controlled trial to evaluate the efficacy and tolerability of hydroxychloroquine and a retrospective study in adult patients with mild to moderate coronavirus disease 2019 (COVID-19). PLoS One 2020; 15:1-14.

https://doi.org/10.1371/journal. pone.0242763

23. Chen $\mathrm{Z}$, $\mathrm{Hu}$ J, Zhang $\mathrm{Z}$, Jiang $\mathrm{S}$, Han S, Yan D, et al. Efficacy of hydroxychloroquine in patients with COVID-19: results of a randomized clinical trial. medRxiv 2020; 03.22.20040758

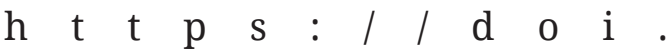
org/10.1101/2020.03.22.20040758

24. Skipper CP, Pastick KA, Engen NW, Bangdiwala AS, Abassi M, Lofgren $\mathrm{SM}$, et al. Hydroxychloroquine in nonhospitalized adults with early COVID-19 : A Randomized Trial. Ann Intern Med 2020; 173(8):623-31.
https://doi.org/10.7326/M20-4207

25. Tang W, Cao Z, Han M, Wang Z, Chen J, Sun W, et al. Hydroxychloroquine in patients with mainly mild to moderate coronavirus disease 2019: Open label, randomised controlled trial. BMJ 2020; 369:1-11. https://doi.org/10.1136/bmj.m1849

26. Cavalcanti AB, Zampieri FG, Rosa RG, Azevedo LCP, Veiga VC, Avezum $A$, et al. Hydroxychloroquine with or without Azithromycin in mild-tomoderate COVID-19. N Engl J Med 2020; 383(21):2041-52.

https://doi.org/10.1056/NEJMoa2019014

27. Walmsley S, Bernstein B, King $M$, Arribas J, Beall G, Ruane P, et al. Ritonavir versus Nelfinavir for the initial treatment of HIV infection. N Engl J Med 2002; 346(26):2039-46.

https://doi.org/10.1056/NEJMoa012354

28. Levin B, Thompson JL. A trial of lopinavir-ritonavir in COVID-19. N Engl J Med 2020; 382(21):e68. https://doi.org/10.1056/NEJMc2008043

29. Horby PW, Mafham M, Bell JL, Linsell L, Staplin N, Emberson J, et al. Lopinavir-Ritonavir in patients admitted to hospital with COVID-19 (RECOVERY): a randomised, controlled, open-label, platform trial. Lancet 2020; 396(10259):1345-52.

https://doi.org/10.1016/S01406736(20)32013-4

30. Cao B, Wang Y, Wen D, Liu W, Wang J, Fan G, et al. A trial of lopinavirritonavir in adults hospitalized with severe COVID-19. N Engl J Med 2020; 382(19):1787-99.

https://doi.org/10.1056/NEJMoa2001282

31. Dolin R, Hirsch MS. Remdesivir - An important first step. N Engl J Med 2020; 383(19):1886-7. https://doi.org/10.1056/NEJMe2018715

32. Beigel JH, Tomashek KM, Dodd LE, Mehta AK, Zingman BS, Kalil AC, et al. Remdesivir for the treatment of COVID-19 - final report. N Engl J Med 2020; 383(19):1813-26.

https://doi.org/10.1056/NEJMoa2007764

33. Spinner CD, Gottlieb RL, Criner GJ, Arribas López JR, Cattelan AM, 
Soriano Viladomiu A, et al. Effect of remdesivir vs standard of care on clinical status at 11 days in patients with moderate COVID-19: A randomized clinical trial. JAMA 2020; 324(11):1048-57. https://doi.org/10.1001/jama.2020.16349

34. Goldman JD, Lye DCB, Hui DS, Marks KM, Bruno R, Montejano R, et al. Remdesivir for 5 or 10 days in patients with severe COVID-19. N Engl J Med 2020; 383(19):1827-37. https://doi.org/10.1056/NEJMoa2015301

35. Wang Y, Zhang D, Du G, Du R, Zhao J, Jin Y, et al. Remdesivir in adults with severe COVID-19: a randomised, double-blind, placebo-controlled, multicentre trial. Lancet 2020; 395(10236):1569-78.

https://doi.org/10.1016/S01406736(20)31022-9

36. Dyer O. COVID-19: Remdesivir has little or no impact on survival, WHO trial shows. BMJ 2020; 371:m4057. https://doi.org/10.1136/bmj.m4057

37. Lee VJ, Yap J, Cook AR, Chen MI, Tay $\mathrm{JK}$, Tan $\mathrm{BH}$, et al. Oseltamivir ring prophylaxis for containment of 2009 H1N1 Influenza outbreaks. N Engl J Med 2010; 362(23):2166-74.

https://doi.org/10.1056/NEJMoa0908482

38. Pusat Informasi Obat Nasional, BPOM RI. OSELTAMIVIR [Internet]. [cited 2021 Jan 6]. Available from: http://pionas.pom.go.id/monografi/ oseltamivir

39. Tan Q, Duan L, Ma Y, Wu F, Huang Q, Mao K, et al. Is oseltamivir suitable for fighting against COVID-19: in silico assessment, in vitro and retrospective study. Bioorg Chem 2020; 104:104257.

ht tp s://d oi.org/10.1016/j . bioorg.2020.104257

40. Chen J, Cai Q, Yang M, Liu D, Shu D, Xia J, et al. Experimental treatment with favipiravir for COVID-19: an openlabel control study. Engineering (Beijing) 2020; 6(10):1192-8.

https://doi.org/10.1016/j.eng.2020.03.007
41. Doi Y, Hibino M, Hase R, Yamamoto M, Kasamatsu Y, Hirose M, et al. A prospective, randomized, open-label trial of early versus late favipiravir therapy in hospitalized patients with COVID-19. Antimicrob Agents Chemother 2020; 64(12): e01897-20. https://doi.org/10.1128/AAC.01897-20

42. RC Group, Horby P, Lim WS, Emberson JR, Mafham M, Bell JL, et al. Dexamethasone in hospitalized patients with COVID-19 - preliminary report. N Engl J Med 2020; NEJMoa2021436.

https://doi.org/10.1056/NEJMoa2021436

43. BPOM RI. Tingkatkan angka kesembuhan dan turunkan angka kematian pasien COVID-19, Badan POM terbitkan izin penggunaan dalam kondisi darurat obat favipiravir dan remdesivir [Internet]. [cited 2021 Jan 5]. Available from: https://www.pom.go.id/new/view/ more/pers/565/Tingkatkan-AngkaKesembuhan-dan-Turunkan-AngkaKematian-Pasien-COVID-19--BadanPOM-Terbitkan-Izin-Penggunaandalam-Kondisi-Darurat-ObatFavipiravir-dan-Remdesivir.html

44. Tomazini BM, Maia IS, Cavalcanti $A B$, Berwanger $O$, Rosa RG, Veiga $\mathrm{VC}$, et al. Effect of dexamethasone on days alive and ventilatorfree in patients with moderate or severe acute respiratory distress syndrome and COVID-19: The CoDEX Randomized Clinical Trial. JAMA 2020; 324(13):1307-16.

https://doi.org/10.1001/jama.2020.17021

45. Corral-Gudino L, Bahamonde A, Arnaiz-revillas F, Gómez-barquero J, Abadía-Otero J, García-Ibarbia C, et al. GLUCOCOVID : A controlled trial of methylprednisolone in adults hospitalized with COVID-19 pneumonia. medRxiv 2020; preprint. $\mathrm{h}$ t $\mathrm{t}$ p s : / / d o i . org/10.1101/2020.06.17.20133579 